\title{
Heterotrophic metabolism in a forest stream sediment: surface versus subsurface zones
}

\author{
Anna M. Romaní, Andrea Butturini, Francesc Sabater, Sergi Sabater* \\ Departament d'Ecologia, Facultat de Biologia, Universitat de Barcelona, Avgda Diagonal 645, E-08028 Barcelona, Spain
}

\begin{abstract}
The heterotrophic metabolism of a forest stream sediment was studied during leaf fall, immediately after a flood that completely scoured and homogenized the first 10 to $12 \mathrm{~cm}$ of sediment. After this event, differences were found between the surface sediment ( 0 to $3 \mathrm{~cm}$ depth) and the subsurface sediment ( 7 to $10 \mathrm{~cm}$ depth). Higher extracellular enzymatic and respiratory activities were measured in the surface than in the subsurface sediment. The higher heterotrophic activity was related to the higher quantity and quality of the organic matter, which accumulated in the surface sediment (higher chlorophyll and bacterial densities). The heterotrophic metabolism in the surface sediment followed a marked seasonal pattern that correlated with the variations in the environmental parameters (discharge, nutrients). However, no temporal pattern was observed in the subsurface sediment, less affected by the physical changes (e.g. scouring), where no significant change in any activity was recorded throughout the study period. There was a significant decrease in heterotrophic metabolism in the subsurface sediments. This difference can be attributed to the lower availability of algae-derived material in the subsurface sediments.
\end{abstract}

KEY WORDS: Biofilm - Metabolism - Sediments - Riparian - Stream - Hyporheos - Ectoenzymatic activities

\section{INTRODUCTION}

Stream biofilms are microbial populations of bacteria, algae, fungi, protozoans and micrometazoans embedded in a polysaccharide matrix inhabiting rocks, gravels, wood and sediments (Lock 1993). Microbial biofilms living in the sediments convert allochthonous or autochthonous dissolved organic substances (Naiman et al. 1987) into particulate form (Kaplan \& Bott 1983, Bott et al. 1984). Sediment biofilms develop a key role in the maintenance of the carbon balance in streams (Marxsen 1988, Meyer 1988). In the hyporheic zone, defined as the sediments hydrologically linked to the open stream channel (Findlay 1995) but above groundwater (White 1993), biofilm metabolism and organic carbon cycling are as tightly coupled as in surface sediments (Bärlocher \& Murdoch 1989, Hedin 1990). The metabolic activity measured in the hyporheic zones is high (Grimm \& Fisher 1984, Hendricks

\footnotetext{
- Addressee for correspondence.

E-mail: ssabater@porthos.bio.ub.es
}

1993, Pusch \& Schwoerbel 1994). The organic matter accumulated in stream sediments is decomposed by bacteria, fungi and occasionally algae, which convert high-molecular-weight molecules to low-molecularweight ones by extracellular enzymatic hydrolysis (Chróst 1990, Marxsen \& Witzel 1991).

Metabolism of biofilm sediments is affected by physical factors such as hydrology and permeability (Hakenkamp et al. 1993, Findlay 1995), leading to heterogeneity in biological and physicochemical patterns in the hyporheic zone (Palmer 1993). Streambed permeability, mainly controlled by grain size (Findlay 1995), favours the water exchange between the surface and the hyporheic sediments (Grimm \& Fisher 1984).

In this study we focused on heterotrophic metabolism in the sediment of a Mediterranean forest stream (Riera Major). Organic matter accumulates in sandy stretches, where the hyporheic zone extends up to $50 \mathrm{~cm}$ in depth. Sand sediments are therefore an important place of carbon storage and cycling. Our study started immediately after a severe flood occurred in Riera Major in October 1994 that completely 
scoured all stored materials from the stream bottom and homogenized the stream sediment to a depth of 10 to $12 \mathrm{~cm}$. This event took place before the leaf fall and gave us an opportunity to compare the changes in surface sediment ( 0 to $3 \mathrm{~cm}$ depth) and the subsurface sediment ( 7 to $10 \mathrm{~cm}$ depth) over an 11 mo period, starting from an organic-matter-free situation. Our aim was to find out whether there were differences in utilization of organic matter by the heterotrophic community of the surface and subsurface sediment over time after the flood. The metabolism of the 2 sediment compartments was estimated from the extracellular enzymatic $(\beta$-glucosidase, $\beta$-xylosidase and phosphatase) and respiration activities, as well as bacterial density and chlorophyll and organic matter content

\section{METHODS}

Study site. Riera Major is an undisturbed secondorder stream located in NE Spain (Sabater \& Romaní 1996). The riparian vegetation is well developed and mainly dominated by alders Alnus glutinosa. Development of riparian vegetation restricts the amount of light reaching the streambed during spring and summer, therefore limiting benthic primary productivity (Guasch \& Sabater 1994). Riera Major is an oligotrophic stream of moderately alkaline waters that drains a siliceous watershed (Martí \& Sabater 1996). Average flow was $60 \mathrm{l} \mathrm{s}^{-1}$ during the study period (October 1994 to August 1995) but the mid-October flood increased discharge to $722 \mathrm{l} \mathrm{s}^{-1}$. Previous experiments performed in this stream provided us with background data about the heterotrophic metabolism of the sediment before the flood (Table 1), which allowed us to control the removal effect of the flood on the benthic activity and biomass.

Table 1. Biofilm metabolism and biomass in Riera Major (NE Spain) sediments before the flood (January to September 1994) and right after the flood (November 1994 to January 1995). Values are means of monthly averages and standard deviations. ETS: electron transport system

\begin{tabular}{|c|c|c|c|}
\hline & \multicolumn{2}{|c|}{ Before flood } & After flood \\
\hline & $\begin{array}{l}\text { Mean } \\
(\mathrm{n}=8)\end{array}$ & $\mathrm{SD}$ & $\begin{array}{c}\text { Mean } \\
(\mathrm{n}=4)\end{array}$ \\
\hline Bacterial density $\left(10^{10} \mathrm{~g}^{-1}\right)$ & 2.37 & 1.78 & $0.28 \quad 0.16$ \\
\hline Chlorophyll ( $\left.\mu g^{-1}\right)$ & 2.63 & 1.67 & $1.45,1.48$ \\
\hline Organic matter (mg AFDW $\mathrm{g}^{-1}$ ) & 9.34 & 4.11 & 5.5311 .91 \\
\hline$\beta$-Glucosidase $\left(\mathrm{nmol} \mathrm{g} \mathrm{g}^{-1} \mathrm{~h}^{-1}\right)$ & 30.37 & 12.83 & $16.50 \quad 2.62$ \\
\hline$\beta$-Xylosidase $\left(\right.$ nmol g-1 $\left.\mathrm{h}^{-1}\right)$ & 13.67 & 6.81 & $7.09 \quad 2.13$ \\
\hline Phosphatase (nmol g-1 $\mathrm{h}^{-1}$ ) & 32.70 & 24.86 & 17.6516 .22 \\
\hline $\operatorname{ETS}\left(\mu g g^{-1} h^{-1}\right)$ & 1.82 & 1.07 & $0.65 \quad 0.24$ \\
\hline
\end{tabular}

Sampling. Sand samples were taken every $15 \mathrm{~d}$ for the first 2 mo after the flood (October to December 1994), and monthly until the end of the experiment (December 1994 to August 1995). A metallic corersampler $(7 \mathrm{~cm}$ diameter) was used for collecting sand samples ( 6 replicates) in a stretch of the stream where leaf accumulation occurred. The first $3 \mathrm{~cm}$ of sediment was considered surface sediment, that between 4 and $6 \mathrm{~cm}$ was discarded to avoid edge effects and that between 7 and $10 \mathrm{~cm}$ was considered subsurface sediment. Sand samples (with a volume of about $2 \mathrm{ml}$ ) were placed in sterile glass vials and kept cold in the dark until arrival at the laboratory. Sand samples for bacterial counting were fixed with a $2 \%$ formaldehyde solution $(w / v)$.

At each sampling date, temperature, $\mathrm{pH}$, dissolved oxygen and conductivity were measured in stream and subsurface water. A manual pump was used to sample subsurface water using 2 bores previously installed in the stream. Water samples were filtered through precombusted Whatman GF/F filters and analyzed for inorganic nutrients (nitrate, ammonium and soluble reactive phosphorus, SRP), dissolved organic carbon (DOC) and dissolved inorganic carbon (DIC) (3 replicates per sample analyzed). Nitrate was analyzed by ion chromatography (Kontron) with an IC-Pack anion column $(4.5 \times 50 \mathrm{~mm})$ and an ultraviolet detector. Ammonium and SRP were analyzed spectrophotometrically (Perkin-Elmer, Lambda2 UV/VIS spectrophotometer) following the procedure of Grasshoff et al. (1983). The DIN:SRP ratio was calculated as the molar ratio of dissolved inorganic nitrogen (DIN) to SRP. DIC and DOC were measured using a total organic carbon analyzer (TOC-5000, Shimadzu).

Water velocity was measured in the field by recording the increase in conductivity with time after a slug injection of a concentrated chloride solution into the stream water, approximately $50 \mathrm{~m}$ upstream from the sampling point (Gordon et al. 1993). Discharge was calculated from mass balance by integration of the concentration hydrograph (Triska et al. 1989).

Particulate organic matter (POM) transported by the stream was collected with a net $(230 \mu \mathrm{m}$ pore, $20 \times$ $20 \mathrm{~cm}$ ) placed in the stream for $2 \mathrm{~min}$. The volume of stream water in the sample was calculated by multiplying the cross sectional area of the net by the velocity of water, and by the measuring time. The material accumulated was dried for $2 \mathrm{~d}$ at $110^{\circ} \mathrm{C}$ and weighed.

Bacterial density, chlorophyll and organic matter content. Bacterial density was measured after sonication of the sand samples for $90 \mathrm{~s}$ (6 replicates per sand compartment) (Romani 1997). The samples were then diluted (dilution factor of 10 to 40 ), fixed and stained with $2 \mu \mathrm{g} \mathrm{ml}^{-1}$ DAPI for $5 \mathrm{~min}$, filtered through $0.2 \mu \mathrm{m}$ irgalan black stained polycarbonate filters (Nucle- 
pore) and counted under a fluorescence microscope (Reichert-Jung, Polyvar) under $1250 \times$ magnification. 20 fields were counted per filter for a total of 400 to 1500 organisms.

Chlorophyll a was measured in surface and subsurface sand samples (6 replicates per type) after extraction in $90 \%$ acetone for $12 \mathrm{~h}$ in the dark at $4^{\circ} \mathrm{C}$. To complete the chlorophyll extraction the samples were finally sonicated for $4 \mathrm{~min}$. Chlorophyll a concentration was determined spectrophotometrically (Perkin-Elmer, Lambda2 UV/VIS spectrophotometer) after filtration (GF/F Whatman filter) of the extract, following Jeffrey \& Humphrey (1975).

Organic matter in surface and subsurface sand samples (6 replicates per type) was measured as ash-free dry weight (AFDW), after combustion of the sand samples at $450^{\circ} \mathrm{C}$ for $4 \mathrm{~h}$, and expressed as $\mathrm{mg} \mathrm{g}^{-1}$ of dry weight.

Microbial metabolism. Extracellular $\beta$-D-glucosidase (EC 3.2.1.21), $\beta$-D-xylosidase (EC 3.2.1.37) and phosphatase (EC 3.1.3.1-2) potential activities were determined spectrofluorometrically using MUF- (methylumbelliferyl)-substrate analogues (4-MUF- $\beta$-Dglucoside, 4-MUF- $\beta$-D-xyloside, and 4-MUF-phosphate from Sigma-Aldrich). Surface and subsurface sand samples (6 replicates per type with a volume of about $2 \mathrm{ml}$ ), formaldehyde-killed controls (sand samples kept in $40 \%$ formaldehyde solution for $30 \mathrm{~min}$ before the assay), and MUF-substrate blanks were incubated with $2 \mathrm{ml}$ of each MUF-substrate solution in filter-sterilized stream water $\left(0.3 \mathrm{mmol} \mathrm{I}^{-1}\right.$, which was high enough to achieve substrate saturation) (Sabater \& Romaní 1996). Incubations were performed in the dark with continuous shaking for $1 \mathrm{~h}$ at ambient stream temperature. Two blanks of filter-sterilized stream water were also incubated. After addition of $0.05 \mathrm{M}$ glycine buffer, $\mathrm{pH} 10.4$ (1/1 v/v ratio buffer/sample), fluorescence was measured at $455 \mathrm{~nm}$ under $365 \mathrm{~nm}$ excitation (Kontron, SFM25). Quantification was achieved by calibrating the spectrofluorometer with a standard alkaline solution of MUF.

Respiratory activity (Electron Transport activity, ETS) was assayed by measuring the reduction of the electron transport acceptor INT (2-(p-iodophenyl)-3(p-nitrophenyl)-5-phenyl tetrazolium chloride) to INTformazan (iodonitrotetrazolium formazan) (Blenkinsopp \& Lock 1990). Six replicates per sample and 2 controls (samples kept in $40 \%$ formaldehyde solution for $30 \mathrm{~min}$ before the assay) were incubated in $0.02 \%$ INT solution in filter-sterilized stream water. Incubations were performed in a shaker at stream temperature for 10 to $12 \mathrm{~h}$ in the dark. INT-formazan was extracted with cold methanol for at least $1 \mathrm{~h}$ at $4^{\circ} \mathrm{C}$ in the dark and sonicated for $2 \mathrm{~min}$. The extracts were then filtered (GF/F filters, Whatman) and the absorb- ance measured spectrophotometrically (Perkin-Elmer, Lambda2 UV/VIS spectrophotometer) at $480 \mathrm{~nm}$. A stock solution of $30 \mu \mathrm{g} \mathrm{ml^{-1 }}$ INT-formazan (Aldrich) in methanol was used to prepare a standard curve.

All the samples used for the biomass and metabolic measurements were dry weighed (after 2 d at $110^{\circ} \mathrm{C}$ ) and the results were expressed per $g$ of sand dry weight.

Statistical analysis. Correlation analysis of the metabolic parameters with environmental variables was performed using a product-moment Pearson coefficient. Correlation was also used to elucidate differences in the temporal pattern of microbial metabolisin between surface and subsurface sediments. Differences in metabolic activities and biomass between sampling dates were analyzed with a 1-way analysis of variance (ANOVA) and compared using a Tukey's multiple comparison test. Differences between surface and subsurface water and sediment metabolism for the whole study period were analyzed by a $t$-test of paired samples.

\section{RESULTS}

\section{Physical and chemical parameters}

Physicalal and chemical parameters in stream water and subsurface water (Table 2) were not significantly different ( $t$-test, $\mathrm{p}>0.05)$. A significant correlation was found between DOC and discharge in surface water $(\mathrm{r}=0.75, \mathrm{p}<0.001, \mathrm{n}=51)$.

The discharge dynamics and POM transported in Riera Major are shown in Fig. 1. After the main flood in October ( $722 \mathrm{l} \mathrm{s}^{-1}$ ), 2 minor successive floods took place in early November (264 $\mathrm{l} \mathrm{s}^{-1}$ ) and in early December (175 $\mathrm{l} \mathrm{s}^{-1}$ ). Afterwards, discharge decreased gradually. POM transported in the stream water was very high for a short period ( 2 to $3 \mathrm{wk}$ ), reaching values of 6 to $7 \mathrm{mg}$ dry weight $1^{-1}$.

\section{Organic matter and biomass}

Content of benthic organic matter (Fig. 2a) was slightly but significantly higher in the surface sediment (Table 3). In this compartment, it reached a peak $2 \mathrm{wk}$ after the main flood, coinciding with the autumnal leaf fall and the highest POM value in stream water, but, due to the large fluctuations, no significant differences were found between sampling dates (ANOVA, $\mathrm{p}=$ 0.37 ). In the subsurface sediment, benthic organic matter was more constant over the study period, with no significant differences observed between sampling dates (ANOVA, $\mathrm{p}=0.41$ ). 
Table 2. Physical and chemical characteristics of Riera Major stream water and subsurface water during the study period. SRP soluble reactive phosphorus; DOC/DIC: dissolved organic/inorganic carbon

\begin{tabular}{|c|c|c|c|c|c|c|c|c|}
\hline & \multicolumn{4}{|c|}{ Surface water } & \multicolumn{4}{|c|}{ Subsurface water } \\
\hline & Min. & Max. & Average & SD & Min. & Max. & Average & SD \\
\hline Temperature $\left({ }^{\circ} \mathrm{C}\right)$ & 3.1 & 16.0 & 8.5 & 4.2 & 3.2 & 13.2 & 8.5 & 3.0 \\
\hline Conductivity $\left(\mu \mathrm{S} \mathrm{cm}^{-1}\right)$ & 126.0 & 205.0 & 175.8 & 30.3 & 129.5 & 209.0 & 177.9 & 30.2 \\
\hline $\mathrm{pH}$ & 7.4 & 8.3 & 8.0 & 0.3 & 7.6 & 8.1 & 7.9 & 0.2 \\
\hline Oxygen (mg l$\left.~^{-1}\right)$ & 9.2 & 12.3 & 10.5 & 1.1 & 7.8 & 12.4 & 10.6 & 1.7 \\
\hline $\mathrm{NO}_{3}-\mathrm{N}\left(\mu \mathrm{g} \mathrm{I}^{-1}\right)$ & 269.0 & 601.2 & 426.5 & 120.2 & 254.7 & 629.5 & 423.8 & 140.0 \\
\hline $\mathrm{NH}_{4}-\mathrm{N}\left(\mu \mathrm{g} \mathrm{I}^{-1}\right)$ & 2.2 & 46.8 & 18.0 & 15.0 & 0.4 & 51.1 & 18.7 & 17.1 \\
\hline $\operatorname{SRP}\left(\mu \mathrm{g} \mathrm{I}^{-1}\right)$ & 2.2 & 18.7 & 10.0 & 6.0 & 3.0 & 20.7 & 12.2 & 7.0 \\
\hline $\mathrm{DOC}\left(\mathrm{mg} \mathrm{l}^{-1}\right)$ & 1.5 & 6.0 & 3.0 & 1.4 & 2.5 & 6.1 & 3.9 & 1.2 \\
\hline $\mathrm{DIC}\left(\mathrm{mg} \mathrm{l}^{-1}\right)$ & 11.2 & 24.0 & 18.5 & 5.2 & 11.3 & 23.3 & 18.6 & 4.5 \\
\hline
\end{tabular}

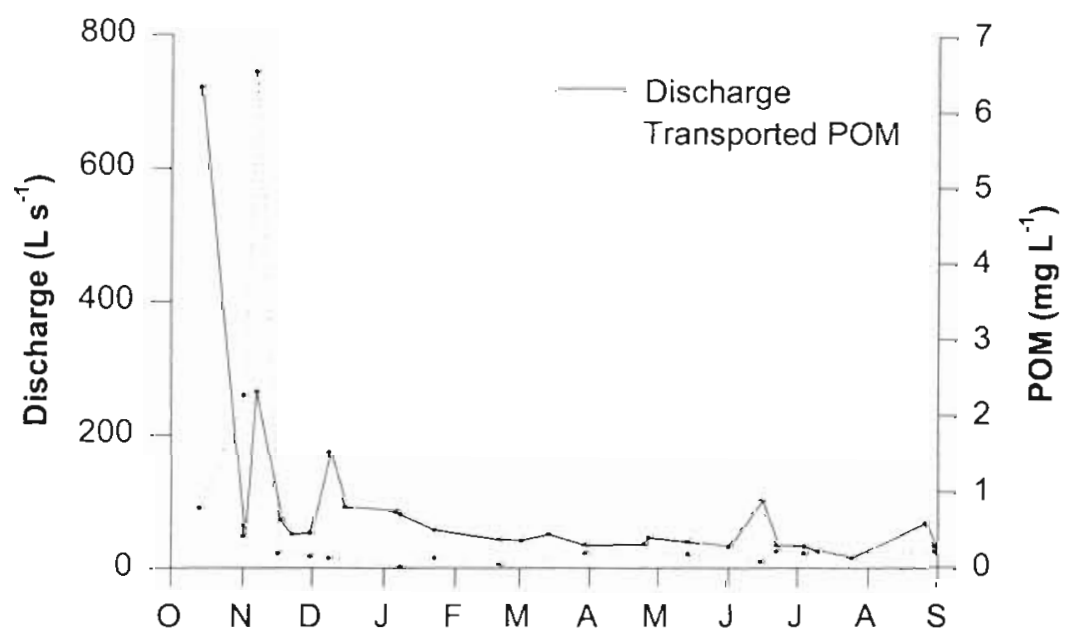

Fig. 1. Temporal variation of discharge and transported particulate organic matter (POM) in the Riera Major (NE, Spain) stream, October 1994 to August 1995 and bacterial density (ANOVA, p < 0.0001 ); the values increased to a significant peak in June (Tukey's test, p < 0.05), decreasing again in July. Fluctuations of bacterial density and chlorophyll content were lower in the subsurface sediment (Fig. 2b, c). No significant differences were observed between sampling dates for chlorophyll (ANOVA, $p=0.06$ ) in the subsurface sediment, and a significant peak of bacterial density occurred only in August (Tukey's test, $\mathrm{p}<0.05$ ). In the surface sediment, both chlorophyll and bacterial density correlated negatively with discharge and DOC, whereas in the subsurface sediment only bacterial density negatively correlated with discharge (Table 4). Bacterial densities in both compartments were significantly correlated with temperature (Table 4).

The chlorophyll/organic matter ratio (chl/OM) was calculated for both surface and subsurface compartments. This ratio was used as an indication of the 'qual-
Bacterial cell density and chlorophyll content were significantly higher in the surface sediment (Table 3), where both parameters followed a similar pattern (Fig. 2b, c, Table 4). Differences between sampling dates in this compartment were significant for both chlorophyl

Table 3. Extracellular enzymes and respiration activities and biomass on surface and subsurface sediments from Riera Major. Values are means and standard deviations for the study period. Differences between the 2 compartments are expressed by the $t$-test - Significantly higher values for the surface sediment. ETS: electron transport system

\begin{tabular}{|c|c|c|c|c|c|}
\hline & \multicolumn{2}{|c|}{ Surface sediment } & \multicolumn{2}{|c|}{ Subsurface sedıment } & \multirow{2}{*}{$\begin{array}{c}t \text {-test } \\
\text { probability }\end{array}$} \\
\hline & Mean $(\mathrm{n}=51)$ & $\mathrm{SD}$ & Mean $(\mathrm{n}=51)$ & $\mathrm{SD}$ & \\
\hline Bacterial density $\left(10^{10} \mathrm{~g}^{-1}\right)$ & $0.83^{\circ}$ & 0.68 & 0.30 & 0.25 & $<0.0001$ \\
\hline Chlorophyll $\left(\mathrm{Ng} \mathrm{g}^{-1}\right)$ & $3.67^{\circ}$ & 4.90 & 0.44 & 0.52 & $<0.0001$ \\
\hline Organic matter (OM) (mg AFDW $\mathrm{g}^{-1}$ ) & 11.91 & 16.46 & 6.72 & 3.74 & 0.018 \\
\hline ChlJOM ratio $\left(10^{-4}\right)$ & $6.17^{\circ}$ & 8.08 & 1.63 & 5.02 & $<0.001$ \\
\hline$\beta$-Glucosidase (nmol g-1 $\mathrm{h}^{-1}$ ) & $18.48^{\circ}$ & 7.52 & 9.89 & 4.66 & $<0.0001$ \\
\hline$\beta$-Xylosidase $\left(\right.$ nmol g $\left.{ }^{1} h^{-1}\right)$ & $8.05^{\circ}$ & 3.06 & 3.79 & 2.22 & $<0.0001$ \\
\hline Phosphatase (nmol g $\mathrm{h}^{-1}$ ) & $34.01^{\circ}$ & 21.24 & 23.59 & 12.76 & $<0.0001$ \\
\hline $\operatorname{ETS}\left(\mu \mathrm{g} \mathrm{g} \mathrm{g}^{-1} \mathrm{~h}^{-1}\right)$ & $0.81^{\circ}$ & 0.73 & 0.36 & 0.18 & $<0.0001$ \\
\hline
\end{tabular}



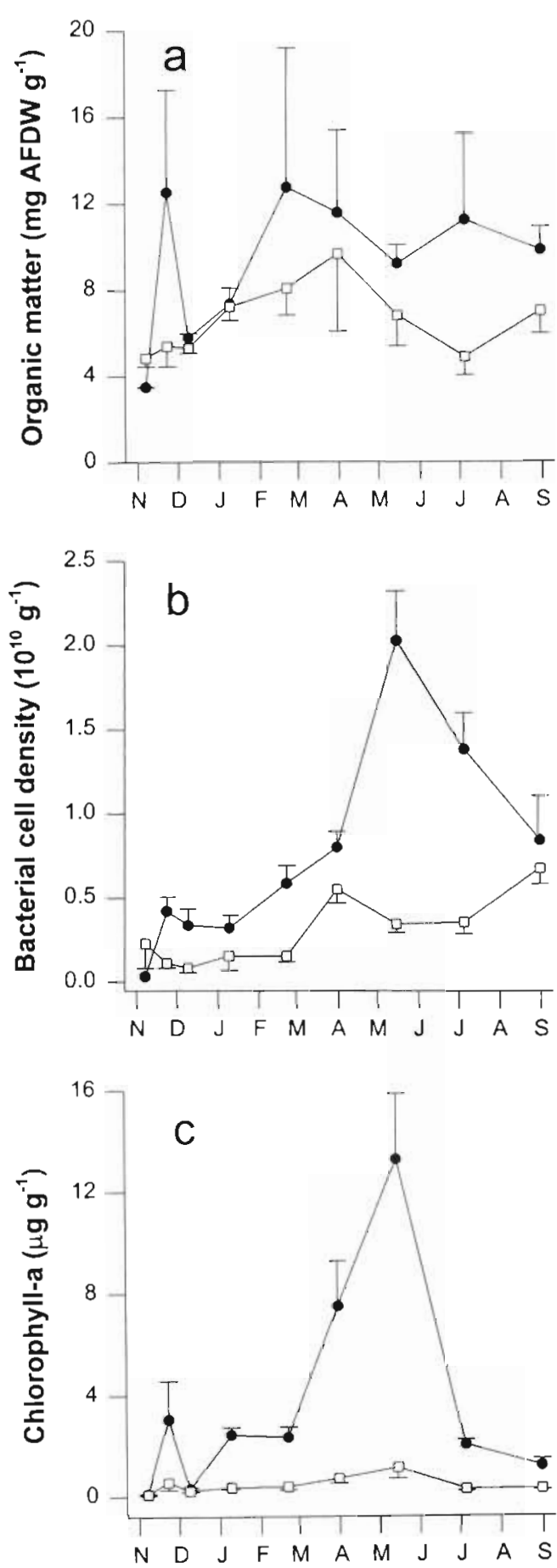

Fig. 2. Temporal variation of benthic biomass and organic matter in surface sediment $(\bullet)$ and subsurface sediment ( $(\square)$ in Riera Major stream, October 1994 to August 1995. Means \pm standard errors (vertical bars), $\mathrm{n}=6$

ity' of the material accumulated in the sediment, since it is related to the different sources of organic matter (autochthonous/allochthonous). Significantly higher values of this ratio were observed in the surface sediment (Table 3).

\section{Microbial metabolism}

Enzymatic and respiratory activites were significantly higher in the surface than in the subsurface sediment (Table 3).

$\beta$-Glucosidase and $\beta$-xylosidase activities followed a similar trend in the surface sediment, with significant differences between sampling dates (ANOVA, $\mathrm{p}=$ 0.009 for $\beta$-glucosidase, $p=0.0001$ for $\beta$-xylosidase) and a peak in June (Tukey's test, $\mathrm{p}<0.05$ ) (Fig. 3a, b). In subsurface sediments, no significant differences were found between sampling dates (ANOVA, $p=0.31$ for $\beta$-glucosidase, $p=0.23$ for $\beta$-xylosidase). $\beta$-glucosidase and $\beta$-xylosidase activities correlated with chlorophyll density and bacterial density in surface sediment, but only with chlorophyll density in subsurface sediment (Table 4 ). $\beta$-Glucosidase activity correlated with $\beta$-xylosidase activity in the 2 sediment compartments (Table 4).

The pattern of variation observed for phosphatase activity was similar in the surface and subsurface sediments ( $r=0.84, p=0.004, n=9$, Fig. 3c), differences between sampling dates being significant in the 2 compartments (ANOVA, $p<0.0001$ ). The lowest values were measured in November, increasing later until spring. This activity was correlated with the bacterial density, the DIN:SRP ratio and the discharge, but also with chlorophyll density and DOC in surface sediments (Table 4). Phosphatase activity in the subsurface zone also correlated negatively with SRP (Table 4).

Respiratory (ETS) activity (Fig. 3d) was significantly higher in surface than in subsurface sediments (Table 3). Community respiration increased gradually in the former compartment, reaching a significant peak in July (Tukey's test, $\mathrm{p}<0.05$ ). Subsurface values of community respiration were not significantly different over the study period (ANOVA, $p=0.47$ ). ETS activity was correlated with bacterial density, DOC and discharge in the surface sediment, but no significant correlation was found in the subsurface sediment (Table 4).

The benthic activities and biomass measured in this study decreased with respect to background data obtained before the flood. There was an important decrease (ca $50 \%$ ) in extracellular enzymatic activity, organic matter and chlorophyll, and an even more drastic reduction in respiration activity (ca 70\%) and bacterial cell density (ca $80 \%$ ) in the stream sediment (Table 1).

\section{DISCUSSION}

The scouring and transport effects of the flood provided excellent conditions for this investigation. After 
Table 4. Significant Pearson correlation coefficients between the heterotrophic activities, biomass and physicochemical parameters in surface and subsurface sediments from Riera Major. Significance: $\cdots p<0.001, \cdots p<0.01, \cdot p<0.05$, no star: $p<0.1$; $n=51$. ETS: electron transport system

\begin{tabular}{|c|c|c|c|c|c|c|c|c|}
\hline & Bact. & Chl. & $\beta$-Gluc. & DOC & SRP & DIN:SRP & Temp. & Disch. \\
\hline \multicolumn{9}{|c|}{ Surface sediment } \\
\hline Bacteria & & & & $-0.53 \cdots$ & & & $0.42 \cdots$ & $-0.43 \cdots$ \\
\hline Chlorophyll & $0.62 \cdots$ & & & $-0.36 \cdots$ & & & & $-0.35^{\circ}$ \\
\hline B-Glucosidase & $0.59 \cdots$ & $0.46^{\circ}$ & & & & & & \\
\hline$\beta$-Xylosidase & $0.40^{\circ}$ & $0.33^{\circ}$ & $0.59 \cdots$ & & & & & \\
\hline Phosphatase & $0.39^{\cdots}$ & $0.51 \cdots$ & & $-0.53 \cdots$ & & $0.28^{\circ}$ & & $-0.33^{*}$ \\
\hline ETS & $0.42^{\cdots}$ & & & $-0.33^{*}$ & & & & $-0.31^{\bullet}$ \\
\hline \multicolumn{9}{|c|}{ Subsurface sediment } \\
\hline Bacteria & & & & & & & $0.37^{\circ}$ & $-0.35^{\circ}$ \\
\hline$\beta$-Glucosidase & & $0.49 \cdots$ & & & & & & \\
\hline B-Xylosidase & & $0.44 \cdots$ & $0.76^{\cdots}$ & & & & & \\
\hline Phosphatase & $0.44 \cdots$ & & & & $-0.32^{*}$ & 0.23 & $0.41 \cdots$ & $-0.42 \cdots$ \\
\hline
\end{tabular}

the flood, the organic matter utilization was mainly based on the new material accumulated, where the accumulation of leaves from the riparian forest was especially relevant.
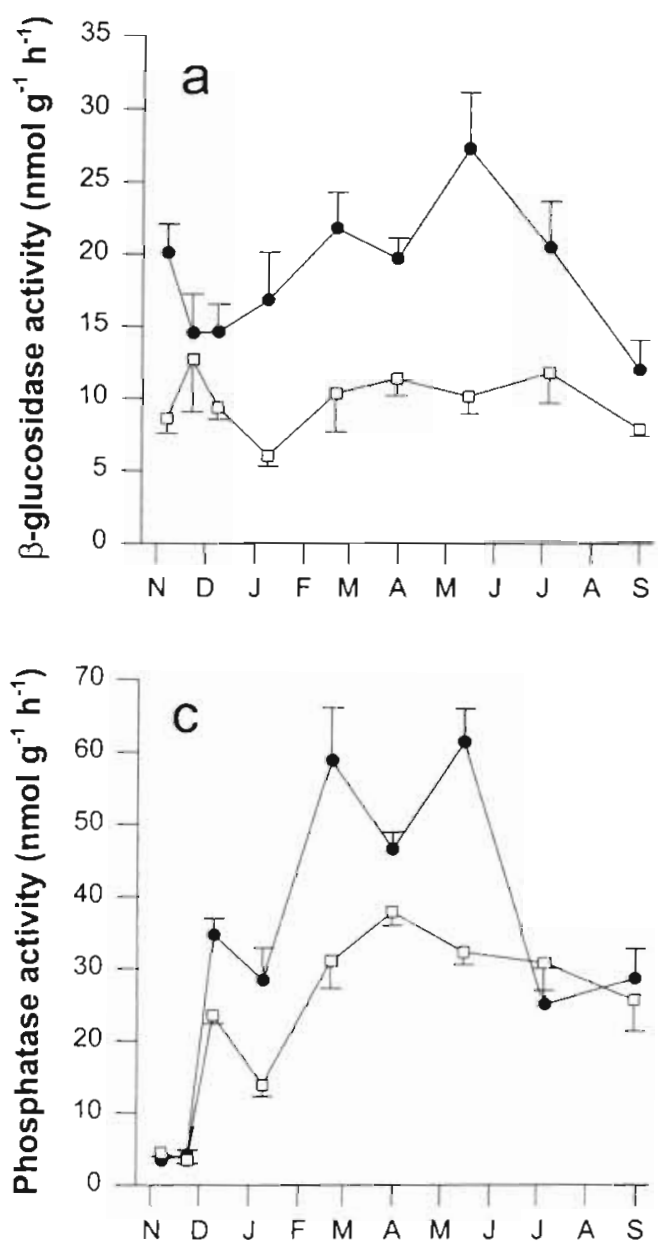

After the flood, significant differences were found in the metabolic activities and biomass between the sediment compartments (Table 3). A decrease in microbial enzymatic activities with depth has been ob-
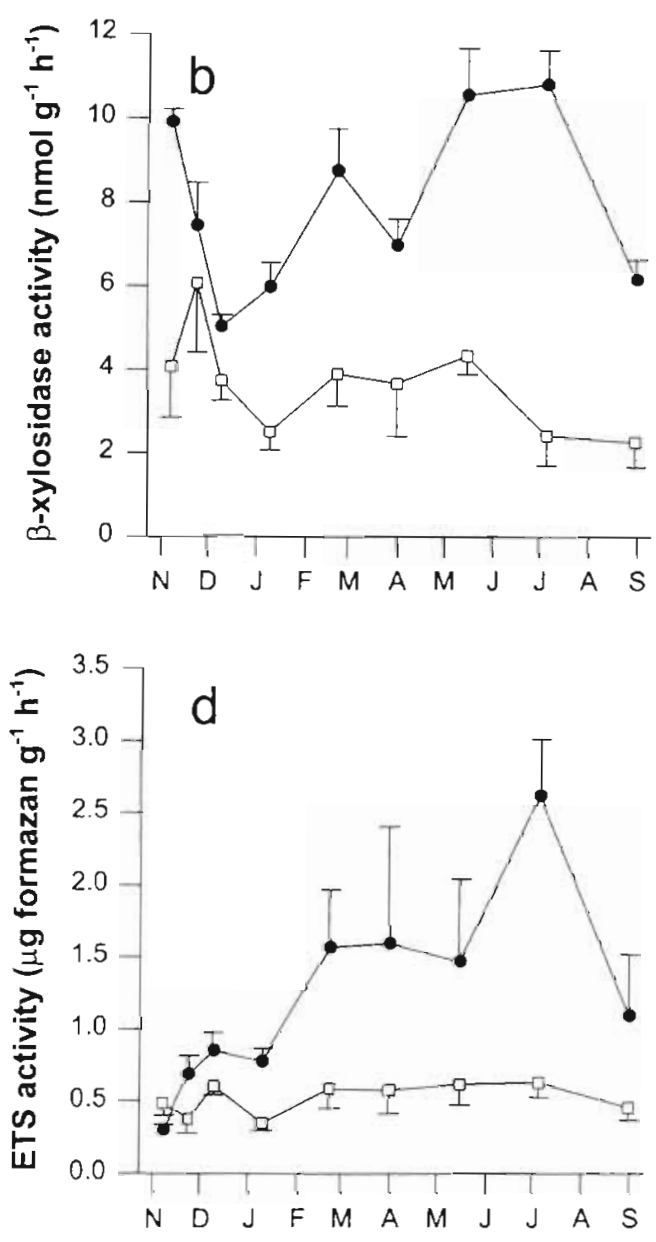

Fig. 3. Temporal variation of extracellular enzymatic and respiratory activities in surface sediment ( $\bullet$ ) and subsurface sediment () in Riera Major stream, October 1994 to August 1995. Means \pm standard errors (vertical bars), $n=6$ 
served in marine and freshwater sediments (MeyerReil 1986, Poremba \& Hoppe 1995, Sala 1995), the decrease being related to sedimentation and accumulation of particulate organic matter produced in the photic zone (e.g. Cole et al. 1988). However, vertical variations of hydrolytic enzymes in stream sediments reveal the existence of other factors than those that play a relevant role in planktonic environments. The lack of significant differences between the nutrient content in surface and subsurface water (Table 2) reflects the important water exchange that takes place, partially caused by the sediment grain size (median particle diameter $693.2 \mu \mathrm{m}$, Romani 1997). Therefore it is possible that other variables apart from nutrients are causing the metabolic differences observed between the surface and the subsurface sediment.

Two reasons are suggested for these metabolic differences. Firstly, the higher amount of organic matter accumulated in the surface sediment may provide a major quantity of organic carbon to the heterotrophic organisms, and secondly, the higher chlorophyll levels in the surface sediment indicate that there is also a provision of higher quality organic compounds.

In support of the first reason, it has been described that the organic matter content of sediment is important for bacterial colonization and/or as a source of nutrients (Cammen 1982, Bott \& Kaplan 1985, Findlay et al. 1986, 1993). This would explain the higher bacterial density found in the surface sediment. It also seems obvious that, if there are no other limitations, a higher quantity of substrate enhances the metabolic processing by the heterotrophs (e.g. Marxsen 1996).

In support of the second reason, it is well known that the quality of the organic matter affects microbial activity and growth (Kaplan \& Bott 1985, Bärlocher \& Murdoch 1989, Hedin 1990), which are enhanced by the availability of more labile compounds (Middelboe \& Sondergaard 1993). The higher quality of the benthic organic matter accumulated on the surface sediment is revealed by the higher chl/OM ratio (Table 3). Algal material has been defined as 'high quality' organic matter (Kaplan \& Bott 1985) and preferentially utilized by bacteria instead of allochthonous materials (Haak \& McFeters 1982). The importance of fresh organic matter as energy source (indicated by the chlorophyll content) is shown by the significant correlation between the enzymatic activities and chlorophyll levels (Table 4). Furthermore, the greater amount of benthic chlorophyll in the surface sediment reveals that algae/plant remains can also be a better physical substrate for bacterial attachment than more decayed (less fresh) material. Chlorophyll in the surface sediment is largely from algal detritus; living epipelic algae are nearly absent, and primary productivity is not detectable (Romaní 1997).

In contrast, in the subsurface sediment, the chl/OM ratio is about one third of that detected in the surface sediment. The chlorophyll is probably more degraded, indicating that lower quality material accumulates in this compartment (McKinley \& Vestal 1992). This would also be affected by the reduced mechanical abrasion in the subsurface zone (Metzler \& Smock 1990). The lower respiration and enzymatic activities in the subsurface sediment could also be a result of their inhibition by the more recalcitrant DOC in this compartment (Freeman et al. 1990, Hedin 1990).

Apart from empirical differences in the heterotrophic metabolism and biomass, the time pattern in both compartments was very different. The surface sediment showed seasonal fluctuations while a rather constant pattern was observed for the subsurface, as is underlined by the results of the ANOVA analysis. The physical parameters, especially discharge and DOC, affect the benthic metabolism and biomass of the surface sediment (Table 4). However, $\beta$-glucosidase and $\beta$-xylosidase activities in the surface sediment seem to be independent of discharge and DOC. It is possible that these enzymatic activities are proportionally more affected by POM input caused by leaf accumulation. Both enzymes contribute to the degradation of decaying algal and plant material (Sinsabaugh et al, 1994a, b) and a peak of activity was observed at the beginning of the experiment, coinciding with maximum POM. The effects of the physical parameters (e.g. discharge and organic matter input) on microbial activity are much weaker in the subsurface zone than in the surface sediment (Table 4).

The different pattern observed for phosphatase suggests that the activity of this enzyme is mainly controlled by nutrient availability, therefore enhanced when inorganic phosphorus is scarce (Whitton 1991, Klotz 1992). The non-significant differences between surface and subsurface nutrient concentrations indicate that this regulation may affect both sediment compartments to the same extent. Decomposing leaf detritus and the accumulated organic material may be substrates of this enzyme in both surface and subsurface sediments (Elwood et al. 1988, Hansson 1989).

It can be concluded that metabolic processes are slower and steadier in the subsurface sediment, less affected by the physical changes (e.g. scouring) that influence surface sediments. However, there was a significant decrease in heterotrophic metabolism in the subsurface sediments. This difference can be attributed to the lower availability of algae-derived material (which is a source of high-quality organic matter) to the biofilm in the subsurface sediments. 
Acknowledgements. This work was funded by the CICYT (project number AMB93-0403) of the Spanish Ministry of Science. We thank the 'Serveis Cientifics i Tècnics de la Universitat de Barcelona' for its technical help in chemical analysis. We also thank 3 anonymous reviewers for their helpful suggestions. A.M.R. received a grant from the Spanish Ministry of Science (no. AP92-46232731) and A.B. received a grant from the European Community (no EV5V-CT-93-5227) to participate in this project.

\section{LITERATURE CITED}

Bärlocher F, Murdoch JH (1989) Hyporheic biofilms-a potential food source for interstitial animals. Hydrobiologia 184:61-67

Blenkinsopp SA, Lock MA (1990) The measurement of electron transport system activity in river biofilms. Water Res 24:441-445

Bott TL, Kaplan LA (1985) Bacterial biomass, metabolic state, and activity in stream sediments: relation to environmental variables and multiple assay comparisons. Appl Environ Microbiol 50:508-522

Bott TL, Kaplan LA, Kuserk FT (1984) Benthic bacterial biomass supported by streamwater dissolved organic matter. Microb Ecol 10:335-344

Cammen LM (1982) Effect of particle size on organic content and microbial abundance within four marine sediments. Mar Ecol Prog Ser 9:273-280

Chróst RJ (1990) Microbial ectoenzymes in aquatic environments. In: Overbeck J, Chróst RJ (eds) Aquatic microbial ecology: biochemical and molecular approaches. Springer Verlag, New York, p 47-78

Cole JJ, Findlay S, Pace ML (1988) Bacterial production in fresh and saltwater ecosystems: a cross-system overview. Mar Ecol Prog Ser 43:1-10

Elwood JW, Mulholland PJ, Newbold JD (1988) Microbial activity and phosphorus uptake on decomposing leaf detritus in a heterotrophic stream. Verh Int Verein Limnol 23:1209-1218

Findlay S (1995) Importance of surface-subsurface exchange in stream ecosystems: the hyporheic zone. Limnol Oceanogr 40:159-164

Findlay S, Meyer J, Risley R (1986) Benthic bacterial biomass and production in two blackwater rivers. Can J Fish Aquat Sci 43:1271-1276

Findlay S, Strayer D, Goumbala C, Gould K (1993) Metabolism of streamwater dissolved organic carbon in the shallow hyporheic zone. Limnol Oceanogr 38: $1493-1499$

Freeman C, Lock MA, Marxsen J, Jones SE (1990) Inhibitory effects of high molecular weight dissolved organic matter on metabolic processes in contrasted rivers and streams. Freshwater Biol 24:159-166

Gordon ND, McMahon T, Finlayson BL (1993) Stream hydrology, an introduction for ecologists. John Wiley, Chichester

Grasshoff K, Ehrhardt M, Kremling K (198.3) Methods of seawater analysis, 2nd edn. Verlag Chemie, Weinheim

Grimm NB, Fisher SG (1984) Exchange between interstitial and surface water: implications for stream metabolism and nutrient cycling. Hydrobiologia 111:219-228

Guasch H, Sabater S (1994) Primary production of epilithic communities in undisturbed Mediterranean streams. Verh Int Verein Limnol 25:1761-1764

Haak TK. McFeters GA (1982) Microbial dynamics of an epilithic mat community in a high alpine stream. Appl Environ Microbiol 43:702-707
Hakenkamp CC. Valett HM, Boulton AJ (1993) Perspectives on the hyporheic zone: integrating hydrology and biology. Concluding remarks. J N Am Benthol Soc 12:94-99

Hansson LA (1989) The influence of a periphytic biolayer on phosphorus exchange between substrate and water. Arch Hydrobiol 115:21-26

Hedin LO (1990) Factors controlling sediment community respiration in woodland stream ecosystems. Oikos 57:94-105

Hendricks SP (1993) Microbial ecology of the hyporheic zone: a perspective integrating hydrology and biology. J N Am Benthol Soc 12:70-78

Jeffrey SW, Humphrey GF (1975) New spectrophotometric equations for determining chlorophylls $a, b$, and $c$ in higher plants, algae and natural phytoplanktan. Biochem Physiol Pflanzen 167:191-194

Kaplan LA, Bott TL (1983) Microbial heterotrophic utilization of dissolved organic matter in a piedmont stream. Freshwater Biol 13:363-377

Kaplan LA, Bott TL (1985) Acclimation of stream-bed heterotrophic microflora: metabolic responses to dissolved organic matter. Freshwater Biol 15:479-492

Klotz RL (1992) Factors influencing alkaline phosphatase activity of stream epilithon. J Freshwater Ecol 7 : 233-242

Lock MA (1993) Attached microbial communities in rivers. In: Ford TE (ed) Aquatic microbiology: an ecological approach. Blackwell Scientific Publications, Oxford, p 113-138

Martí E, Sabater F (1996) High variability in temporal and spatial nutrient retention in Mediterranean streams. Ecology 77:854-869

Marxsen J (1988) Evaluation of the importance of bacteria in the carbon flow of a small open grassland stream, the Breitenbach. Arch Hydrobiol 111:339-350

Marxsen J (1996) Measurement of bacterial production in stream-bed sediments via leucine incorporation. FEMS Microb Ecol 21:313-325

Marxsen J, Witzel KP (1991) Significance of extracellular enzymes for organic matter degradation and nutrient regeneration in small streams. In: Chróst RJ (ed) Microbial enzymes in aquatic environments. Springer-Verlag, New York, p 270-285

McKinley VL, Vestal JR (1992) Mineralization of glucose and lignocellulose by four arctic freshwater sediments in response to nutrient enrichment. A.ppl Environ Microbiol 58:1554-1563

Metzler GM, Smock LA (1990) Storage and dynamics of subsurface detritus in a sand-bottomed stream. Can J Fish Aquat Sci 47:588-594

Meyer JL (1988) Benthic bacterial biomass and production in a blackwater river. Verh Int Verein Limnol 23:1832-1838

Meyer-Reil LA (1986) Measurement of hydrolytic activity and incorporation of dissolved organic substrates by microorganisms in marine sediments. Mar Ecol Prog Ser 31: 143-149

Middelboe M, Sondergaard M (1993) Bacterioplankton growth yield: seasonal variations and coupling to substrate lability and $\beta$-glucosidase activity. Appl Environ Microbiol 59:3916-3921

Naiman RJ, MeliJlo JM, Lock MA, Ford TE, Reice SR (1987) Longitudinal patterns of ecosystem processes and community structure in a subarctic river continuum. Ecology 68: $1139-1156$

Palmer MA (1993) Experimentation in the hyporheic zone: challenges and prospectus. J $N$ Am Benthol Soc 12: $84-93$

Poremba K, Hoppe HG (1995) Spatial variation of benthic microbial production and hydrolytic enzymatic activity 
down the continental slope of the Celtic Sea. Mar Ecol Prog Ser 118:237-245

Pusch M. Schwoerbel J (1994) Community respiration in hyporheic sediments of a mountain stream (Steina, Black Forest). Arch Hydrobiol 130:35-52

Romaní AM (1997) Heterotrophic and autotrophic metabolism in Mediterraneaz streams. PhD dissertation, University of Barcelona

Sabater S, Romaní AM (1996) Metabolic changes associated with biofilm formation in an undisturbed Mediterranean stream. Hydrobiologia 335:107-113

Sala MM (1995) Caracte:ización de las actividades enzimáticas de las comunidades microbianas en el litoral del lago de Constanza. PhD thesis, Autonomous University of Barcelona

Editorial responsibility: Karel Simek, Ceské Budéjovice, Czech Republic
Sinsabaugh RL, Moorhead DL, Linkins AE (1994a) The enzymic basis of plant litter decomposition: emergence of an ecological process. Appl Soil Ecol 1:97-111

Sinsabaugh RL, Osgood MP. Findlay S (1994b) Enzymatic models for estimating decomposition rates of particulate detritus. J N Am Benthol Soc 13:160-169

Triska FJ, Kennedy VC, Avanzino RJ, Zellweger GW, Bencala KE (1989) Retention and transport of nutrients in a thirdorder stream: channel processes. Ecology 70:1877-1892

White DS (1993) Perspectives on defining and delineating hyporheic zones. J N Am Benthol Soc 12:61-69

Whitton BA (1991) Use of phosphatase assays with algae to assess phosphorus status of aquatic environments. In: Jeffrey DW, Madden B (eds) Bioindicators and environmental management. Academic Press, London, p 295-310

Submitted: December 14, 1997; Accepted: June 2, 1998 Proofs received from author(s): October 30,1998 